\title{
PENGARUH PEMBELAJARAN ONLINE TERHADAP HASIL BELAJAR KOGNITIF MAHASISWA SEKOLAH TINGGI KATOLIK ST YAKOBUS MERAUKE DI MASA PANDEMI COVID-19
}

\author{
Oleh: Yohanes Hendro Pranyoto
}

\begin{abstract}
Abstrak
Tulisan ini dilatarbelakangi oleh situasi dan kondisi yang terjadi di Sekolah Tinggi Katolik (STK) Santo Yakobus Merauke. Di tengah pandemi covid-19, setiap sekolah termasuk perguruan tinggi "dipaksa" untuk mengubah metode dan media belajar mereka dari cara konvensional ke pembelajaran online/daring. Proses transisi yang sangat cepat ini membawa dampak yang cukup signifikan terhadap dinamika pembelajaran di kampus sehingga dapat mempengaruhi hasil belajar mahasiswa. Jenis penelitian ini adalah kuantitatif dengan model analisis regresi. Sampel penelitian adalah mahasiswa-mahasiswi STK sebanyak 60 orang. Instrumen yang digunakan ialah angket dengan model skala Likert. Dari hasil uji validitas pada taraf signifikansi $5 \%, N=60$ orang dengan nilai kritis 0,254 diperoleh sebanyak 34 item valid. Hasil uji reliabilitas diperoleh koefisien alpha sebesar 0,738 yang berarti reliabilitas instrumen tinggi. Dari hasil uji regresi linier sederhana dengan taraf signifikansi 5\%, diperoleh nilai signifikansi pada tabel Anova sebesar 0,000 yang berarti terdapat pengaruh Pembelajaran Online terhadap Hasil Belajar Kognitif. Nilai korelasi sebesar 0,854 yang menunjukkan hubungan yang kuat dan positif antar variabel bebas dengan terikat. Nilai $R$ Square sebesar 0,71 yang berarti pengaruh variabel Pembelajaran Online terhadap Hasil Belajar Kognitif sebesar $71 \%$. Berdasarkan hasil penelitian ini disarankan agar pihak kampus lebih meningkatkan efektivitas dan efisiensi pembelajaran online dengan cara meningkatkan keterampilan dosen dan mahasiswa dalam memanfaatkan modul/aplikasi pembelajaran online, meningkatkan kesiapan sarana-prasarana pendukung (termasuk pemberian subsidi kuota internet), meningkatkan keterampilan dosen dalam mengembangkan modul pembelajaran berbasis daring, serta meningkatkan fungsi kontrol akses internet mahasiswa selama di kampus.
\end{abstract}

Kata Kunci : pembelajaran online, media pembelajaran, hasil belajar kognitif, covid-19

\section{A. Pendahuluan}

$\mathrm{P}$ enggunaan teknologi informasi dan komunikasi saat ini sudah menjadi sebuah life style atau gaya hidup bagi sebagian besar masyarakat, termasuk dalam dunia pendidikan. Pada masa pandemi virus Covid-19 seperti sekarang ini, penggunaan teknologi informasi dan komunikasi dalam dunia pendidikan lebih ditekankan untuk menjaga kontinuitas proses pembelajaran di saat pembelajaran tatap muka secara langsung tidak memungkinkan untuk dilaksanakan di ruang kelas. Teknologi informasi dan komunikasi (TIK) menjadi sebuah instrumen teknologi pembelajaran interaktif berperan dalam menciptakan harmonisasi dan dinamika pembelajaran yang kreatif dan interaktif. Salah satu produk TIK untuk pembelajaran adalah e-learning atau pembelajaran online ${ }^{1}$.

Pada prinsipnya e-learning adalah pembelajaran yang menggunakan jasa elektronika dan digital sebagai alat bantunya. Dalam pendidikan konvensional fungsi $e$ learning bukan untuk mengganti, melainkan memperkuat model pembelajaran konvensional melalui pengayaan konten dan pengembangan teknologi pendidikan. Ariani dan Haryanto mengatakan pemanfaatan teknologi merupakan kebutuhan mutlak dalam dunia pendidikan sehingga sekolah benar-benar menjadi ruang belajar dan tempat

${ }^{1}$ Yazdi, M, E-Learning Sebagai Media Pembelajaran Interaktif Berbasis Teknologi Informasi, Jurnal Ilmiah Foristek, Fakultas Matematika dan Ilmu Pengetahuan Alam Universitas Tadulako, 2012. 
siswa mengembangkan kemampuannya secara optimal, dan nantinya bisa berinteraksi di tengah-tengah masyarakat ${ }^{2}$. Penerapan metode pembelajaran online/daring selama pandemi Covid-19 juga dianjurkan oleh pemerintah melalui Menteri Pendidikan dan Kebudayaan dengan dikeluarkannya Surat Edaran Nomor 15 Tahun 2020 tentang Pedoman Penyelenggaraan Belajar Dari Rumah Dalam Masa Darurat Penyebaran Covid-19.

Berdasarkan hasil observasi peneliti di Sekolah Tinggi Katolik St. Yakobus Merauke, kampus ini sudah memiliki fasilitas pendukung pembelajaran online/daring seperti jaringan wifi/hotspot untuk mahasiswa, laboratorium komputer, server dan modul atau aplikasi pembelajaran online (e-learning). Pada pertengahan semester genap tahun akademik 2019/2020 yang lalu, STK St. Yakobus Merauke sesuai anjuran pemerintah mencoba menerapkan pembelajaran online dalam proses perkuliahannya. Tenaga pendidik dan kependidikan STK St. Yakobus Merauke dilatih khusus untuk menggunakan aplikasi atau modul e-learning yang ada seperti Edlink dan Google Class Room.

Pihak kampus juga memanfaatkan penggunaan media sosial populer sebagai media pembelajaran pendukung seperti Facebook dan Whatsapp. Media sosial dipilih karena mahasiswa pada umumnya lebih biasa menggunakannya dibandingkan dengan aplikasi atau sistem e-learning sepenuhnya seperti: Edlink, Moodle, Chamilo, Claroline, dll. Kendala lain yang dihadapi para dosen dalam melakukan pembelajaran online adalah kemampuan literasi digital mahasiswa untuk modul pembelajaran berbasis online. Mahasiswa khususnya yang datang dari kampung-kampung pedalaman belum terbiasa menggunakan perangkat teknologi informasi dan komunikasi seperti gawai dan akses internet untuk pembelajaran online (e-learning).

Permasalahan tersebut menjadi kendala paling berarti dalam melaksanakan proses pembelajaran online. Banyak mahasiswa yang mengeluhkan kesulitan mengakses jaringan internet, tidak adanya perangkat/gawai yang mendukung dan meskipun memiliki gawai dan jaringan internet namun masih kesulitan menggunakan aplikasi yang ada seperti Edlink dan Google Class Room. Hal ini dapat dimaklumi mengingat implementasi pembelajaran online waktu itu sangat cepat, hampir tidak ada waktu untuk transisi atau peralihan antara pembelajaran konvensional ke pembelajaran online. Oleh karena itu banyak tenaga pendidik maupun peserta didik yang merasa belum siap untuk melaksanakan pembelajaran online. Dampaknya adalah proses pembelajaran yang kurang maksimal sehingga berdampak pada hasil belajar peserta didik dalam konteks ini adalah mahasiswa Sekolah Tinggi Katolik St. Yakobus Merauke.

Berdasarkan situasi dan permasalahan di atas, peneliti tertarik untuk mengangkat judul penelitian: "Pengaruh Pembelajaran Online terhadap Hasil Belajar Kognitif Mahasiswa Sekolah Tinggi Katolik St. Yakobus Merauke". Adapun tujuan yang ingin dicapai dari penelitian ini adalah untuk mengetahui pengaruh dari pembelajaran online di perguruan tinggi terhadap hasil belajar kognitif mahasiswa yang diukur dengan indeks prestasi semester (IPS) semester genap tahun akademik 2019/2020. Hasil belajar kognitif dipilih karena menjadi indikator yang paling mudah diamati dan diukur sebagai dampak dari penerapan pembelajaran online selama semester genap tahun akademik 2019/2020 di Sekolah Tinggi Katolik St. Yakobus Merauke. Hipotesis awal peneliti adalah bahwa penerapan proses pembelajaran online berdampak terhadap hasil belajar mahasiswa, apakah berdampak signifikan dan seberapa besar pengaruhnya akan dibahas lebih lanjut dalam penelitian ini.

2 Ismiasri, T, Pemanfaatan Teknologi Multimedia dalam Pembelajaran Matematika, (Blitar: STKIP, 2011), hlm. 12. 


\section{B. Kajian Teoritis}

\section{Pembelajaran Online}

\section{a. Pengertian Media Pembelajaran}

Media pembelajaran menurut Shulman yang dikutip oleh Elliott, adalah . . the way of representing and formulating the subjects that make it comprehensible to others, and an understanding of what makes the learning of specific topics easy or difficult; the conceptions and preconceptions that student of different ages and backgrounds, bring with them to the learning of those most frequently taught topics and lesson ${ }^{3}$. Media pembelajaran diartikan sebagai cara atau jalan untuk menyampaikan materi pembelajaran agar mudah dimengerti oleh peserta didik

Menurut Winkel media dapat diartikan secara luas dan sempit. Secara luas, media pembelajaran dapat diartikan sebagai setiap orang, materi atau peristiwa yang memberikan kesempatan kepada siswa untuk memperoleh pengetahuan, keterampilan dari sikap, karena itu, tenaga pengajar, buku pelajaran, dan gedung sekolah dapat menjadi suatu media pengajaran. Media pembelajaran jika diartikan secara sempit berarti alat-alat yang menjadi perantara siswa dan materi pelajaran ${ }^{4}$.

Menurut konsep Dc Corte sebagaimana dikutip oleh W.S. Winkel, media pembelajaran adalah suatu sarana non personal yang digunakan oleh tenaga pengajar yang memegang peranan penting dalam proses belajar-mengajar, untuk mencapai tujuan instruksional $^{5}$. Dengan menggunakan media pembelajaran, guru dapat memperkaya, memperluas, dan memperdalam proses belajar-mengajar, lebih-lebih apabila tersedia media yang merangsang lebih dari satu indra manusia.

Istilah media yang kita ketahui sekarang lebih populer dalam bidang komunikasi, namun proses belajar mengajar pada dasarnya juga merupakan sebuah proses komunikasi. Hal inilah yang membuat media yang digunakan dalam pembelajaran disebut media pembelajaran. Media pembelajaran merupakan sarana atau peralatan yang dapat digunakan atau tidak digunakan, tergantung dari tujuan instruksional, keadaan awal siswa secara aktual, materi pelajaran, prosedur didaktis dan bentuk pengelompokan siswa. Tersedianya sejumlah media pembelajaran, memberikan alternatif kepada guru untuk memilih alat mana yang paling sesuai, dengan mempertimbangkan keuntungan dan kelemahan dari masing-masing media pembelajaran tersebut.

\section{b. Jenis Media Pembelajaran}

Jenis media pembelajaran menurut Arief S. Sadiman dikelompokkan menjadi tiga, yaitu media grafis, media audio, dan media proyeksi ${ }^{6}$. Media grafis merupakan media visual yang menyajikan data atau informasi menggunakan simbol, gambar, diagram, grafik yang nampak. Media audio adalah media yang menggunakan suara sebagai sarana penyampaian pesan. Media proyeksi adalah media visual dan/atau audio yang dapat digunakan dengan bantuan proyektor. Hal ini tentunya berbeda dengan media grafik, dimana media proyeksi membutuhkan alat elektronik untuk menampilkan informasi atau sebuah pesan.

\footnotetext{
${ }^{3}$ Elliot, Stephen N., Educational Psychology: Effective teaching, Effective learning, (Boston: McGraw-Hill, 2000).

${ }^{4}$ Winkel, W.S, Psikologi Pengajaran, (Jakarta: Gramedia Widiasarana Indonesia, 1996), hlm. 285.

${ }^{5}$ Ibid, hlm. 285

${ }^{6}$ Arief S. Sadiman, dkk, Media Pendidikan: Pengertian, Pemanfaatan, dan Pengembangannya, (Jakarta: CV. Rajawali, 1996), hlm. 19.
} 
Rudy Bretz dalam bukunya The A Taxonomy of Communication Media, mengklasifikasikan media pembelajaran menjadi delapan, yaitu media audio, media cetak, media visual diam, media visual gerak, media audio semi gerak, media semi gerak, media audio visual diam, dan media audio visual gerak ${ }^{7}$. Sementara itu dari sekian banyak jenis media yakni dapat dimanfaatkan dalam pembelajaran, Henich seperti yang dikutip oleh Aristo, menjelaskan klasifikasi media yang lebih sederhana: (1) media yang tidak diproyeksikan; (2) media yang diproyeksikan; (3) Media audio, (4) media video; (5) media berbasis komputer, dan (6) multimedia kit ${ }^{8}$. Dari pengelompokan media tersebut, belum ada suatu pengelompokan media yang mencakup segala aspek, khususnya untuk keperluan pembelajaran. Pengelompokan yang ada dilakukan atas bermacam-macam kepentingan.

\section{c. Manfaat Media Dalam Pembelajaran}

Beberapa manfaat media dalam pembelajaran menurut Dayton sebagaimana dikutip oleh Aristo adalah : (1) penyampaian materi pelajaran dapat diseragamkan; ( 2 ) proses pembelajaran menjadi lebih jelas dan menarik; (3) proses pembelajaran, menjadi lebih interaktif; (4) efisiensi dalam waktu dan tenaga, (5) meningkatkan kualitas hasil belajar siswa; (6) memungkinkan proses belajar dapat dilakukan di mana saja dan kapan saja; (7) menumbuhkan sikap positif siswa terhadap materi dan proses belajar; dan (8) merubah peran guru ke arah yang lebih positif dan produktif ${ }^{9}$.

Aristo berpendapat bahwa selain beberapa manfaat media, seperti tersebut di atas, kita dapat menemukan banyak manfaat-manfaat praktis yang lain, yaitu : (1) media dapat membuat materi pelajaran yang abstrak menjadi lebih konkret; (2) media juga dapat mengatasi kendala keterbatasan ruang dan waktu; (3) media dapat membantu mengatasi keterbatasan indra manusia; (4) media juga dapat menyajikan obyek pelajaran berupa benda atau peristiwa langka dan berbahaya ke dalam kelas; dan (5) informasi pelajaran yang disajikan dengan media yang tepat akan memberikan kesan mendalam dan lebih lama tersimpan pada diri siswa ${ }^{10}$.

Pada prinsipnya, media pembelajaran di dalam proses belajar mengajar bermanfaat untuk memperjelas penyajian pesan dan informasi sehingga penyampaian pesan menjadi lebih optimal. Media pembelajaran secara langsung maupun tidak langsung mampu membangkitkan motivasi belajar peserta didik sehingga konsentrasi belajar peserta didik pun dapat meningkat. Harapannya dengan penggunaan media pembelajaran dapat meningkatkan kompetensi siswa sehingga hasil belajarnya pun meningkat.

\section{d. Pembelajaran Online (E-learning)}

Istilah pembelajaran online atau e-Learning mengandung pengertian yang sangat luas, sehingga banyak pakar yang menguraikan tentang definisi pembelajaran online atau e-Learning dari berbagai sudut pandang. Salah satu definisi yang cukup dapat diterima banyak pihak misalnya dari Darin E. Hartley yang menyatakan: "e-Learning merupakan suatu jenis belajar mengajar yang memungkinkan tersampaikannya bahan

\footnotetext{
${ }^{7}$ Rudy Bretz, The A Taxonomy of Communication Media, (New Jersey: Educational Technology Publications, 1971), hlm. 17.

${ }^{8}$ Aristo Rahadi, Media Pembelajaran, (Jakarta: Depdiknas, 2003), hlm. 23.

${ }^{9}$ Ibid, hlm. 15 .

${ }^{10}$ Ibid, hl. 18.
} 
ajar ke siswa dengan menggunakan media Internet, Intranet atau media jaringan komputer lain". 11

Secara sederhana e-learning dapat dipahami sebagai suatu proses pembelajaran yang memanfaatkan teknologi informasi berupa komputer yang dilengkapi dengan sarana telekomunikasi (internet, intranet, ekstranet) dan multimedia (grafis, audio, video) sebagai media utama dalam penyampaian materi dan interaksi antara pengajar (guru/dosen) dan pembelajar (siswa/mahasiswa). Pada prinsipnya e-learning adalah pembelajaran yang menggunakan jasa elektronika sebagai alat bantunya. Dalam pendidikan konvensional fungsi e-learning bukan untuk mengganti, melainkan memperkuat model pembelajaran konvensional.

Pembelajaran online di perguruan tinggi khususnya di masa pandemi covid-19 adalah bagian dari pembelajaran jarak jauh untuk meminimalisir kegiatan tatap muka. Pembelajaran online atau e-learning meliputi berbagai aplikasi dan proses seperti computerbased learning, web-based learning atau virtual classroom yang menjadi bagian dari pembelajaran berbasis teknologi yang memanfaatkan sumber daya Internet (on-line). Penggunaan teknologi internet untuk pembelajaran memudahkan guru dan peserta didik untuk melaksanakan proses pembelajaran dari mana saja dan kapan saja.

Seperti yang dijelaskan Cisco mengenai fungsi e-learning sebagai berikut ${ }^{12}$ :

1) E-learning merupakan penyampaian informasi, komunikasi, pendidikan, pelatihan secara off-line atau on-line.

2) E-learning menyediakan seperangkat alat yang dapat memperkaya nilai belajar secara konvensional (model belajar konvensional, kajian terhadap buku teks, CD-ROM, dan pelatihan berbasis komputer) sehingga dapat menjawab tantangan perkembangan globalisasi.

3) E-learning tidak berarti menggantikan model belajar konvensional di dalam kelas, tetapi memperkuat model belajar tersebut melalui pengayaan content dan pengembangan teknologi pendidikan.

4) Kapasitas siswa amat bervariasi tergantung pada bentuk isi dan cara penyampaiannya. Makin baik keselarasan antar content dan alat penyampai dengan gaya belajar, maka akan lebih baik kapasitas siswa yang pada gilirannya akan memberi hasil yang lebih baik.

Model pembelajaran berbasis TIK dengan menggunakan e-learning berakibat pada perubahan budaya belajar dalam konteks pembelajarannya. Setidaknya ada empat komponen penting dalam membangun budaya belajar dengan menggunakan model $e$ learning di sekolah. Pertama, peserta didik dituntut secara mandiri dalam belajar dengan berbagai pendekatan yang sesuai agar siswa mampu mengarahkan, memotivasi, mengatur dirinya sendiri dalam pembelajaran. Kedua, guru mampu mengembangkan pengetahuan dan ketrampilan, memfasilitasi dalam pembelajaran, memahami belajar dan hal-hal yang dibutuhkan dalam pembelajaran. Ketiga tersedianya infrastruktur yang memadai dan yang ke empat administrator yang kreatif serta penyiapan infrastruktur dalam memfasilitasi pembelajaran.

Keuntungan dan keterbatasan online learning menurut Michael Molinda adalah sebagai berikut ${ }^{13}$ :

${ }^{11}$ Darin E. Hartley, Selling E-Learning, (Alexandria: ASTD Publications, 2001), hlm. 1.

12 Yazdi, M, E-Learning Sebagai Media Pembelajaran Interaktif Berbasis Teknologi Informasi, Jurnal Ilmiah Foristek, (Sulawesi Tengah: Universitas Tadulako, 2012), hlm. 146.

${ }^{13}$ Michael Molinda, Instrucsional Technology and Media for Learning, (New Jersey: Colombus, 2005), hlm. 205. 


\section{1) Keuntungan}

a) Internet bisa memuat teks, audio, grafik, animasi video, dll.

b) Bisa di update informasi dan siswa dapat mengakses info tanpa batas.

c) Siswa dapat mengakses informasi kemana-mana tanpa pergi jauh.

d) Siswa dapat berkonsultasi dengan tenaga ahli dan bertukar pendapat dengan siswa yang lain.

e) Berkomunikasi dengan mudah.

f) Tidak terlalu mahal (Murah)

2) Keterbatasan

a) Banyak materi internet yang tidak sesuai dengan materi siswa misalnya: rokok, alkohol, pornografi dll.

b) Mudah terjadi pembajakan atas hak cipta.

c) Sulit mencari informasi karena setiap hari ribuan web tumbuh.

d) Membutuhkan tenaga teknisi untuk mengorganisir LAN/WAN.

e) Membutuhkan alat koneksi untuk dapat mengakses internet.

g) Membutuhkan cara pandang kritis atas informasi yang masuk.

Berdasarkan teknologi informatika yang digunakan, pembelajaran online kemudian dikelompokkan berdasarkan basis teknologi sebagai berikut:

1) Computer Based Training (CBT)

Basis utama proses belajar mengajar ini adalah Program Komputer (Software) yang biasa dipakai untuk belajar secara interaktif dan fleksibel. Biasanya softwaresoftware pelajaran ini berisikan bagian multimedia, seperti animasi dan juga bagian alat untuk menyelesaikan soal-soal latihan. Bagian multimedia biasanya digunakan untuk menjelaskan bahan-bahan pelajaran dan menjadikannya mudah dimengerti oleh pengguna. Dengan menggunakan alat yang disediakan maka pengguna mempunyai kesempatan untuk mencoba soal-soal latihan tanpa batasan jumlah dan tingkat kesulitannya. Sistem CBT ini mulai berkembang di tahun 80-an dan masih berkembang terus sampai sekarang. Hal ini ditunjang antara lain oleh perkembangan sistem animasi yang kian menarik dan realistis (misalnya sistem animasi 3 dimensi). Selain untuk pelajar, sistem ini pun digemari oleh perusahaan-perusahaan untuk mendidik karyawannya. Namun, pada pembelajaran online dengan konsep ini, komunikasi yang terjadi hanya komunikasi satu arah.

2) Web Based Training (WBT)

Sistem ini merupakan perkembangan lanjutan dari CBT dan berbasis teknologi internet. Sehingga dengan menggunakan konsep ini, dapat terjadi komunikasi dua arah antar pengguna. Namun lancarnya proses belajar dengan menggunakan sistem ini bergantung kepada infrastruktur jaringan yang kecepatan tinggi. Kendala penerapan konsep ini terletak pada kenyataan bahwa memang jaringan internet di negara kita masih belum merata khususnya di Indonesia Timur dan pulau-pulau terluar seperti di Papua dimana Sekolah Tinggi Katolik St. Yakobus Merauke berada. Salah satu komponen WBT yang sangat digemari adalah video-conferencing, yaitu dimana peserta didik dan pendidik dapat langsung mendiskusikan semua hal tanpa harus bertemu muka secara langsung. Aplikasi yang memanfaatkan video-conferencing sangat populer seperti Zoom Meeting, Google Meet, Skype, Cisco Webex, Microsoft Teams, Face Time, dll. 


\section{Hasil Belajar Kognitif}

\section{a. Pengertian Hasil Belajar Kognitif}

Belajar adalah aktivitas mental/psikis yang berlangsung dalam interaksi aktif dengan lingkungan yang menghasilkan perubahan-perubahan. Perubahan itu diperoleh melalui usaha (bukan karena kematangan), menetap dalam waktu yang relatif lama dan merupakan hasil pengalaman ${ }^{14}$.

Menurut Purwanto hasil belajar dapat dijelaskan dengan memahami dua kata yang membentuknya, yaitu "hasile dan "belajar". Pengertian hasil (product) menunjukkan pada suatu perolehan akibat dilakukannya suatu aktivitas atau proses yang mengakibatkan berubahnya input secara fungsional.

Kognitif berasal dari kata cognition yang pada dasarnya kata knowing, yang berarti mengetahui. Istilah kognitif menjadi populer sebagai salah satu domain atau wilayah/ranah psikologis manusia yang meliputi setiap perilaku mental yang berhubungan dengan pemahaman, pertimbangan, pengolahan informasi, pemecahan masalah, kesengajaan, dan keyakinan ${ }^{15}$.

Dari pengertian di atas dapat disimpulkan bahwa hasil belajar kognitif mahasiswa adalah kemampuan, kecakapan, atau kapasitas ranah kognitif terkait dengan pengetahuan dan pemahaman tentang metode dan gaya belajar, kemampuan mengembangkan dan mengaplikasikan metode dan gaya belajar di perguruan tinggi, mengelola waktu, menganalisis kesulitan atau tantangan belajar, merangkum atau menyintesis materi belajar hingga menciptakan suatu produk berdasarkan aktivitas belajar yang dialami.

\section{b. Dimensi Hasil Belajar Kognitif}

Hasil belajar kognitif adalah perilaku yang terjadi dalam kawasan kognisi. Proses belajar yang melibatkan kognisi meliputi kegiatan sejak dari penerimaan stimulus eksternal oleh sensori, penyimpanan dan pengolahan dalam otak menjadi informasi hingga pemanggilan kembali informasi ketika diperlukan untuk menyelesaikan masalah. Dalam hubungan dengan satuan pelajaran, ranah kognitif memegang peranan paling utama. Tujuan utama pengajaran pada umumnya adalah peningkatan kemampuan siswa dalam aspek kognitif. Aspek kognitif dibedakan atas enam jenjang menurut taksonomi Bloom yang diurutkan secara hierarki piramidal. Sistem klasifikasi Bloom tersebut dapat digambarkan sebagai berikut ${ }^{16}$ :

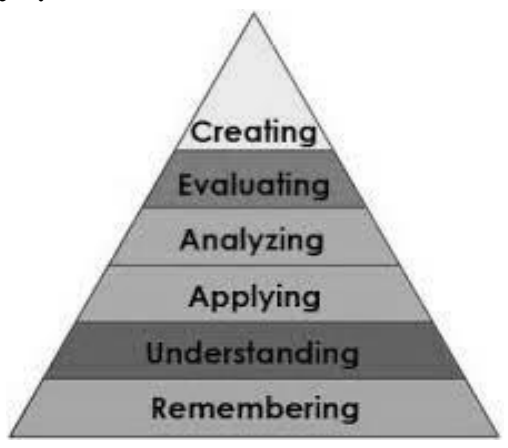

Gambar 1. Taksonomi Bloom

\footnotetext{
${ }^{14}$ Purwanto, Ngalim, Prinsip-prinsip dan Teknik Evaluasi Pengajaran, (Bandung: PT Remaja Rosdakarya, 2010), hlm. 38.

15 Muhibbin Syah, Psikologi Pendidikan dengan Pendekatan Baru, (Bandung: PT Remaja Rosdakarya, 2009), hlm. 65.

16 Daryanto, Evaluasi Pendidikan, (Jakarta: PT Rineka Cipta, 2010), hlm. 101-102.
} 
Berikut ini adalah penjelasan singkat mengenai tiap aspek sebagaimana diberikan dalam taksonomi Bloom.

1) Pengetahuan (Knowledge)

Pengetahuan (Knowledge) adalah kemampuan seseorang untuk mengingat-ingat kembali (recall) atau mengenali kembali tentang nama, konsep, istilah-istilah atau fakta, ide, gejala, rumus-rumus, dan sebagainya tanpa mengharapkan kemampuan untuk menggunakannya ${ }^{17}$.

2) Pemahaman (Comprehension)

Pemahaman (Comprehension) adalah tingkat kemampuan yang mengharapkan peserta didik mampu memahami arti atau konsep, situasi, serta fakta yang diketahuinya. 3) Penerapan (Application)

Penerapan (Application) adalah kesanggupan seseorang untuk menerapkan atau menggunakan ide-ide umum, tata cara ataupun metode-metode, prinsip-prinsip, rumusrumus, teori-teori dan sebagainya, dalam situasi yang baru dan konkret.

4) Analisis (Analysis)

Analisis (Analysis) adalah kemampuan seseorang untuk dapat menguraikan suatu situasi atau keadaan tertentu ke dalam unsur-unsur atau komponen-komponen pembentuknya.

5) Penilaian (Evaluation)

Penilaian (Evaluation) merupakan kemampuan seseorang untuk membuat suatu penilaian tentang suatu pernyataan, konsep, situasi berdasarkan suatu kriteria tertentu.

6) Mencipta (Creating)

Menciptakan mengarah pada proses kognitif meletakkan unsur-unsur secara bersama-sama untuk membentuk kesatuan yang koheren dan mengarahkan siswa untuk menghasilkan suatu produk baru dengan mengorganisasikan beberapa unsur menjadi bentuk atau pola yang berbeda dari sebelumnya.

\section{c. Faktor-faktor yang Mempengaruhi Hasil Belajar}

Menurut Muhibbin Syah faktor-faktor yang dapat mempengaruhi pencapaian hasil belajar peserta didik terdiri dari faktor internal dan eksternal ${ }^{18}$ :

\section{1) Faktor internal}

Faktor internal adalah faktor yaitu faktor yang berasal dari dalam diri siswa atau peserta didik itu sendiri. Terdapat dua faktor internal yaitu :

a) Faktor fisiologis (jasmani)

1. Kondisi jasmani meliputi postur tubuh, kelengkapan dan berfungsinya anggota tubuh secara normal, kebutuhan gizi tubuh, stamina tubuh yang dapat mempengaruhi kemampuan siswa dalam menerima pelajaran.

2. Kondisi pancaindra meliputi kondisi penglihatan, pendengaran, penciuman, perasa dan pengecap.

b) Faktor psikologis (rohaniah, mental dan kepribadian)

1. Tingkat kecerdasan atau intelegensi

2. Sikap belajar siswa

3. Bakat atau potensi yang dimiliki

4. Minat belajar siswa atas suatu topik atau materi

5. Motivasi berprestasi siswa hlm. 50.

7 Anas Sudijono, Pengantar Evaluasi Pendidikan, (Jakarta: PT Rajagrafindo Persada, 2011),

${ }^{18}$ Muhibin Syah, op.cit., hlm. 132-139. 
Dari kedua faktor internal yang sudah dipaparkan di atas, faktor yang dominan adalah faktor psikologis. Oleh karena itu peran dari orang tua, keluarga, guru dan temanteman sangat diperlukan untuk memotivasi siswa dalam belajar. Belajar pertama-tama adalah soal minat dan kemauan, jika seseorang tidak memiliki kehendak yang kuat untuk belajar maka akan sulit menerima stimulus yang diberikan.

\section{2) Faktor eksternal}

Faktor eksternal adalah faktor yang berasal dari luar siswa yaitu kondisi lingkungan di sekitar siswa itu sendiri.

a) Lingkungan sosial, mencakup keluarga, sekolah, masyarakat dan kelompok.

b) Lingkungan non sosial, seperti gedung sekolah dan letaknya, rumah tempat tinggal keluarga siswa dan letaknya, keadaan cuaca, waktu belajar yang digunakan siswa dan bentang alam.

\section{Metode Penelitian}

Penelitian ini menggunakan jenis penelitian kuantitatif dengan model analisis regresi. Analisis regresi adalah metode untuk menentukan hubungan sebab-akibat antara satu variabel dengan variabel yang lain ${ }^{19}$. Lokasi penelitiannya adalah di Sekolah Tinggi Katolik Santo Yakobus Merauke, dengan alamat di Jalan Missi II, Merauke, Papua. Waktu penelitian selama 2 bulan yaitu mulai Juni-Juli 2020.

Populasi penelitian adalah seluruh mahasiswa aktif Sekolah Tinggi Katolik Santo Yakobus Merauke semester genap tahun akademik 2019/2020 sebanyak 175 orang. Dari 175 orang tersebut, peneliti menetapkan sampel penelitian sebanyak 60 orang yang diambil secara proporsional berdasarkan angkatan mahasiswa (stratified random sampling).

Tabel 1. Distribusi Populasi dan Sampel

\begin{tabular}{|c|c|c|c|}
\hline No. & Angkatan & Populasi & Sampel \\
\hline 1 & 2015 & 3 & 1 \\
\hline 2 & 2016 & 41 & 14 \\
\hline 3 & 2017 & 47 & 16 \\
\hline 4 & 2018 & 38 & 13 \\
\hline 5 & 2019 & 46 & 16 \\
\hline & Jumlah & 175 & 60 \\
\hline
\end{tabular}

Teknik pengumpulan data yang digunakan untuk pengumpulan data dalam penelitian ini menggunakan metode angket dengan bentuk skala sikap diferensial semantik untuk variabel bebas (pembelajaran online), sementara untuk variabel terikat (hasil belajar kognitif), peneliti menggunakan skor Indeks Prestasi Semester (IPS) mahasiswa pada semester genap tahun akademik 2019/2020. Skala diferensial semantik berisikan serangkaian karakteristik bipolar untuk mengungkapkan indikator dari variabel bebas dan variabel terikat. Instrumen ini bersifat tertutup, artinya responden tinggal menyatakan sikapnya atas pernyataan yang disediakan melalui jawaban yang sesuai antara range selalu-tidak pernah dan setuju-tidak setuju.

Uji coba instrumen ini bersifat uji coba terpakai dalam arti peneliti hanya satu kali menyebarkan instrumen untuk dipakai dalam mengumpulkan data. Instrumen yang sudah diisi responden akan diuji tingkat validitas dan reliabilitasnya, butir instrumen

19 Sugiyono, Metode Penelitian Kuantitatif, Kualitatif dan R\&D, (Bandung: Alfabeta, 2012), hlm. 11. 
yang memiliki nilai validitas rendah $(\leq 0,254, \alpha=0,05, N=60)$ akan dibuang dan tidak dipakai dalam analisa data. Sedangkan yang memenuhi syarat dalam uji validitas dan reliabilitas akan dipakai untuk menguji hipotesis.

Setelah alat ukur telah diuji validitas dan reliabilitasnya, maka tahap selanjutnya ialah uji persyaratan analisis data meliputi uji normalitas data, uji linearitas dan uji heterokedastisitas untuk menentukan apakah hipotesis akan diuji secara parametrik atau non parametrik. Teknik dalam pengujian hipotesis menggunakan teknik analisis regresi sederhana dengan bantuan program SPSS versi 25.0 dengan melihat nilai signifikansi pada tabel Anova dan Coefficients kemudian membandingkannya dengan taraf signifikansi $(\alpha) 0,05$. Adapun ketentuan penerimaan atau penolakan, ialah apabila nilai signifikansi kurang dari atau sama dengan $(\leq)$ 0,05 maka hipotesis kerja diterima dan hipotesis nihil ditolak, dan apabila lebih dari 0,05 (>) maka hipotesis kerja ditolak dan hipotesis nihil diterima. Adapun hipotesis dalam penelitian ini adalah sebagai berikut: Hipotesis Kerja (Ha) : Terdapat pengaruh pembelajaran online terhadap hasil belajar kognitif mahasiswa STK St. Yakobus Merauke

Hipotesis Nihil (H0) : Tidak terdapat pengaruh pembelajaran online terhadap hasil belajar kognitif mahasiswa STK St. Yakobus Merauke

\section{Hasil Penelitian dan Pembahasan}

\section{Hasil Pengujian Validitas dan Reliabilitas}

Hasil pengujian validitas, dari 40 butir instrumen yang diuji, terdapat 6 (enam) butir yang tidak valid karena memiliki skor kurang dari $(<) 0,254$, dengan demikian terdapat 34 butir instrumen yang valid dan layak untuk dianalisis lebih lanjut. Dalam penelitian ini instrumen variabel hasil belajar tidak perlu diuji validitas dan reliabilitasnya karena peneliti menggunakan nilai Indeks Prestasi Semester (IPS) semester genap tahun akademik 2019/2020 yang berasal dari analisis dan pengolahan data akademik yang sudah divalidasi oleh masing-masing dosen pengampu mata kuliah. Hasil pengujian reliabilitas terhadap 40 butir soal, diketahui nilai Alpha sebesar 0,738 yang berarti reliabilitas soal tinggi untuk variabel pembelajaran online.

Tabel 2. Reliability Statistics

\begin{tabular}{|r|r|r|}
\hline $\begin{array}{c}\text { Cronbach's } \\
\text { Alpha }\end{array}$ & $\begin{array}{l}\text { Cronbach's Alpha } \\
\text { Based on } \\
\text { Standardized Items }\end{array}$ & N of Items \\
\hline .738 & .746 & 40 \\
\hline
\end{tabular}

\section{Hasil Pengujian Persyaratan Analisis (Uji Asumsi Klasik)}

Hasil pengujian normalitas berdasarkan Normal Probability Plot (gambar 2) terlihat bahwa sebaran data disekitar garis lurus dan titik-titik data membentuk pola linear sehingga konsisten dengan distribusi normal dengan demikian data pada variabel penggunaan media sosial sebagai media pembelajaran dan hasil belajar kognitif mahasiswa adalah normal. Dari tabel Anova (tabel 3) diketahui nilai linearity sebesar 0,000 atau lebih kecil $(<)$ dari nilai signifikansi 0,05 sehingga dapat dikatakan data bersifat linier. Artinya dua variabel yang diteliti memiliki hubungan yang linier dan signifikan. 


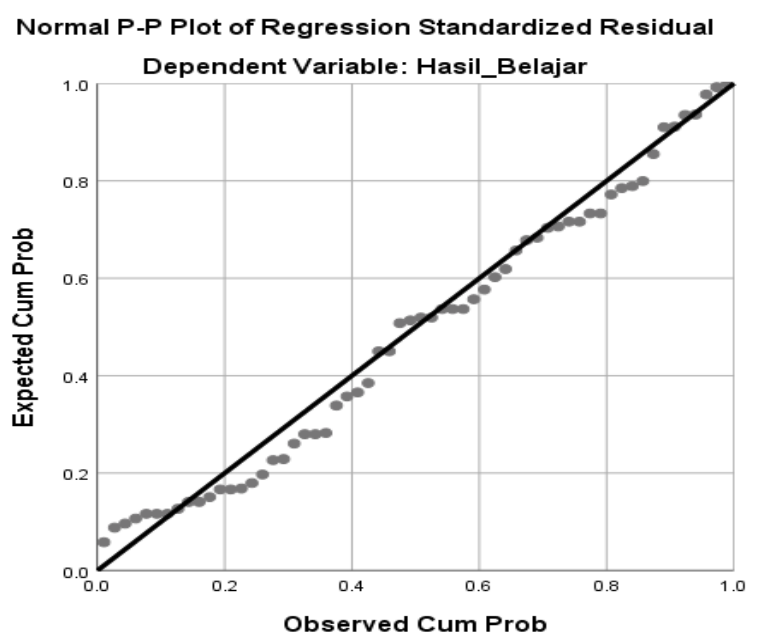

Gambar 2. Normal Probability Plot

Tabel 3. Anova

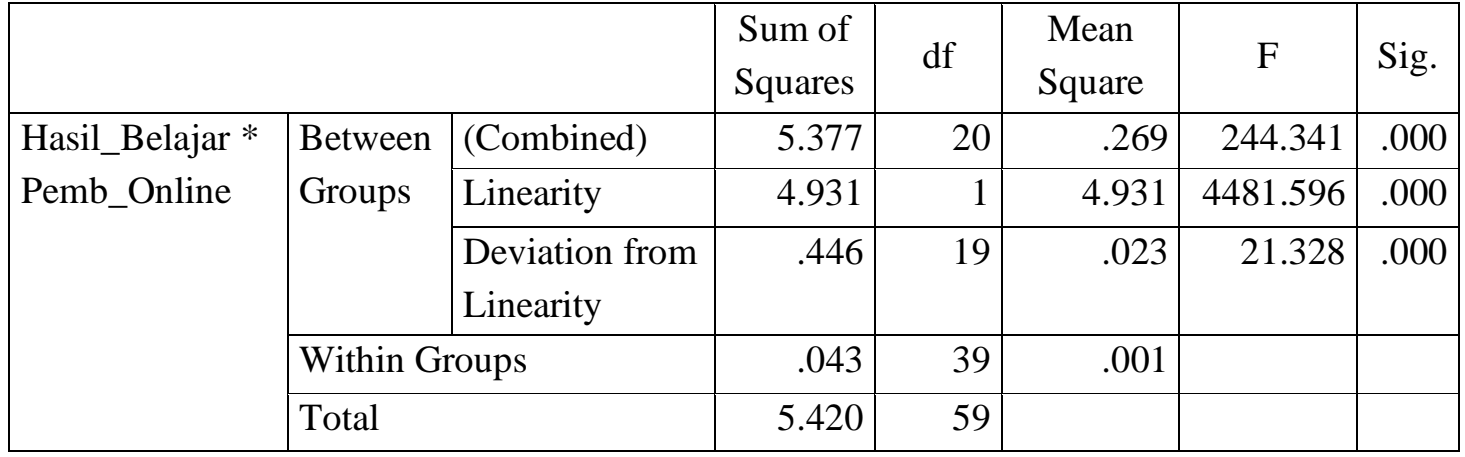

Pengujian heterokedastisitas melalui program SPSS 25.0 dilihat dari grafik scaterplot (gambar 3). Dari grafik diketahui bahwa sebaran data terdistribusi secara merata atau tidak membentuk suatu pola tertentu, dan titik-titik menyebar di atas dan di bawah angka 0 pada sumbu Y. Jadi dapat disimpulkan bahwa tidak terjadi masalah heterokedastisitas dalam model regresi yang dianalisis.

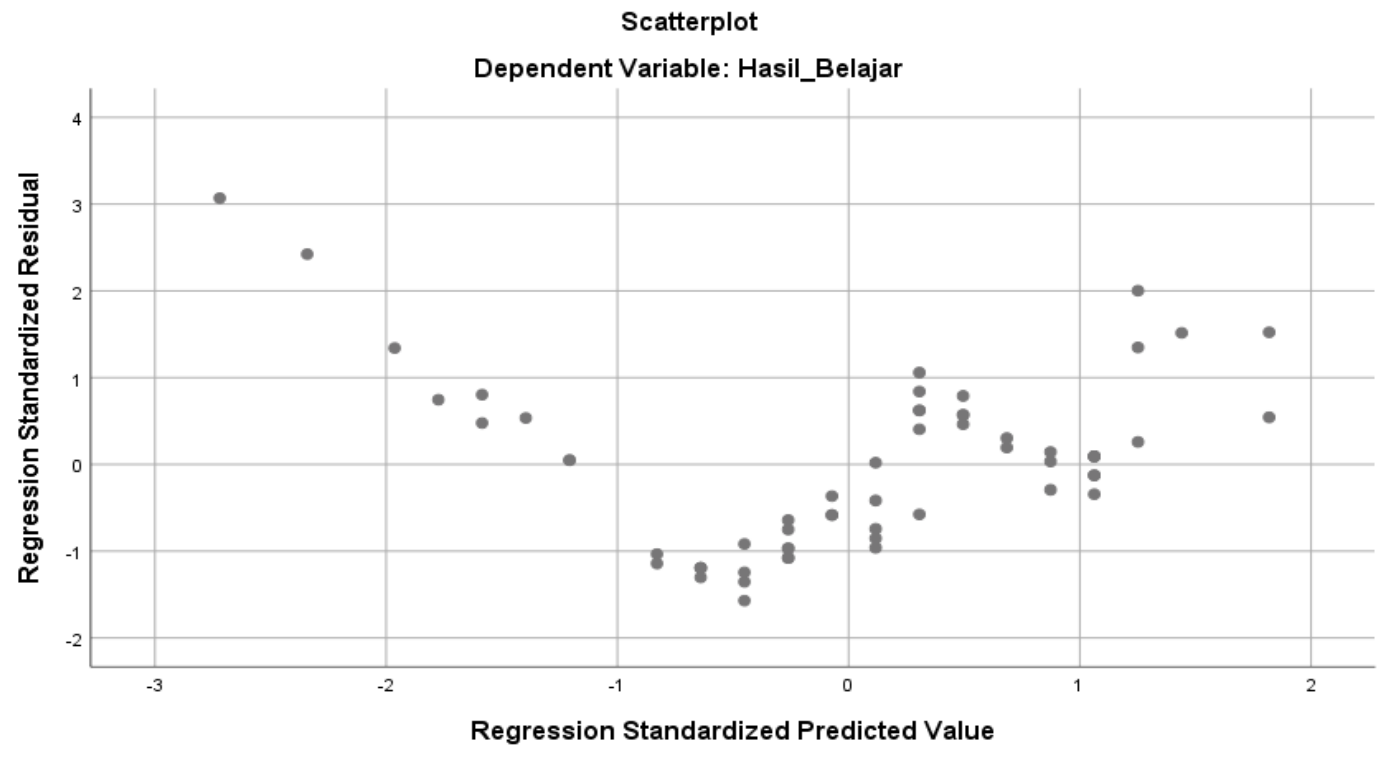

Gambar 3. Scatterplot 


\section{Uji Hipotesis}

Dari tabel 4 di bawah diketahui nilai signifikansi sebesar 0,000 yang berarti lebih kecil dari taraf signifikansi 0,05 . Hal ini menunjukkan bahwa ada pengaruh antara variabel bebas (pembelajaran online) terhadap variabel terikat (hasil belajar kognitif), oleh karena itu Ha (hipotesis alternatif) diterima dan H0 (hipotesis nihil) ditolak.

Tabel 4. Anova

\begin{tabular}{|l|l|r|r|r|r|r|}
\hline \multicolumn{2}{|c|}{ Model } & \multicolumn{1}{|c|}{$\begin{array}{c}\text { Sum of } \\
\text { Squares }\end{array}$} & df & Mean Square & F & Sig. \\
\hline \multirow{3}{*}{1} & Regression & 4.931 & 1 & 4.931 & 585.127 & $.000^{\mathrm{b}}$ \\
\cline { 2 - 7 } & Residual & .489 & 58 & .008 & & \\
\cline { 2 - 7 } & Total & 5.420 & 59 & & & \\
\hline
\end{tabular}

a. Dependent Variable: Hasil_Belajar

b. Predictors: (Constant), Pemb_Online

Tabel 5. Correlations

\begin{tabular}{|l|l|r|r|}
\hline \multicolumn{2}{|c|}{} & Hasil_Belajar & Pemb_Online \\
\hline \multirow{2}{*}{ Pearson Correlation } & Hasil_Belajar & 1.000 & .854 \\
\cline { 2 - 4 } & Pemb_Online & .854 & 1.000 \\
\hline \multirow{2}{*}{ Sig. (1-tailed) } & Hasil_Belajar &. & .000 \\
\cline { 2 - 4 } & Pemb_Online & .000 &. \\
\hline \multirow{2}{*}{ N } & Hasil_Belajar & 60 & 60 \\
\cline { 2 - 4 } & Pemb_Online & 60 & 60 \\
\hline
\end{tabular}

Dari tabel 5 di atas diketahui nilai korelasi antara dua variabel sebesar 0,854 yang berarti ada hubungan yang sangat kuat dan positif (mendekati 1) antara variabel bebas dan terikat. Hal ini menunjukkan bahwa penggunaan media pembelajaran online dan hasil belajar kognitif saling berhubungan erat (timbal balik).

Tabel 6. Model Summary ${ }^{\mathrm{b}}$

\begin{tabular}{|c|c|c|c|c|c|c|c|c|c|}
\hline \multirow[b]{2}{*}{ Model } & \multirow[b]{2}{*}{$\mathrm{R}$} & \multirow[b]{2}{*}{$\begin{array}{c}\mathrm{R} \\
\text { Squar } \\
\mathrm{e}\end{array}$} & \multirow[b]{2}{*}{$\begin{array}{l}\text { Adjusted R } \\
\text { Square }\end{array}$} & \multirow[b]{2}{*}{$\begin{array}{c}\text { Std. Error } \\
\text { of the } \\
\text { Estimate }\end{array}$} & \multicolumn{5}{|c|}{ Change Statistics } \\
\hline & & & & & $\begin{array}{c}\mathrm{R} \\
\text { Square } \\
\text { Change } \\
\end{array}$ & $\begin{array}{c}\text { F } \\
\text { Change }\end{array}$ & df1 & df2 & $\begin{array}{l}\text { Sig. F } \\
\text { Change }\end{array}$ \\
\hline 1 & $.754^{\mathrm{a}}$ & .710 & .708 & .09180 & .710 & 585.127 & 1 & 58 & .000 \\
\hline \multicolumn{10}{|c|}{ a. Predictors: (Constant), Pemb_Online } \\
\hline b. Dep & adent $\mathrm{V}$ & ariable: & Hasil_Belaja & & & & & & \\
\hline
\end{tabular}

Berdasarkan data pada tabel Model Summary di atas diketahui nilai R Square sebesar 0,710 yang berarti pengaruh variabel bebas terhadap variabel terikat sebesar $71 \%$. Hal ini menunjukkan bahwa variabel pembelajaran online dapat mempengaruhi hasil belajar mahasiswa STK St. Yakobus Merauke pada masa pandemi covid-19 secara signifikan sebesar $71 \%$. Selain dipengaruhi oleh media pembelajaran online, hasil belajar kognitif mahasiswa STK St. Yakobus Merauke di masa pandemi covid-19 juga dipengaruhi oleh variabel lain yang tidak diteliti sebesar $29 \%$. 
Tabel 7. Coefficients ${ }^{\mathrm{a}}$

\begin{tabular}{|c|c|c|c|c|c|c|}
\hline & \multirow[t]{2}{*}{ Model } & \multicolumn{2}{|c|}{ Unstandardized Coefficients } & $\begin{array}{c}\text { Standardized } \\
\text { Coefficients }\end{array}$ & \multirow[t]{2}{*}{$\mathrm{t}$} & \multirow[t]{2}{*}{ Sig. } \\
\hline & & B & Std. Error & Beta & & \\
\hline \multirow{2}{*}{1} & (Constant) & 4.296 & .280 & & 15.351 & .000 \\
\hline & Pemb_Online & .024 & .002 & .899 & 13.016 & .000 \\
\hline
\end{tabular}

Dari tabel 7 di atas diketahui nilai konstanta/intercept ( $\beta$ ) sebesar 4,296 dan nilai slope $(\alpha)$ sebesar 0,055 . Konstanta bernilai positif yang menunjukkan adanya pengaruh positif antara variabel bebas terhadap variabel terikat. Dari tabel 7 di atas dapat diperoleh rumus persamaan regresi sebagai berikut: $Y=4,296+0,024 X$. Artinya jika pembelajaran online bernilai konstan (0) maka hasil belajar kognitif mahasiswa adalah sebesar 4,296. Apabila nilai pembelajaran online naik 10 poin, maka hasil belajar kognitif mahasiswa naik menjadi 4,536 dan sebaliknya.

\section{E. Simpulan dan Saran}

1. Simpulan

Berdasarkan hasil penelitian dapat disimpulkan beberapa hal sebagai berikut:

a. Dari hasil pengujian hipotesis diperoleh nilai signifikansi sebesar $0,000(<0,05)$ yang berarti Ha diterima dan Ho ditolak, dengan kata lain terdapat pengaruh positif dan signifikan dari pembelajaran online (variabel bebas) terhadap hasil belajar kognitif mahasiswa STK Santo Yakobus Merauke di masa pandemi covid-19. Nilai korelasi antara variabel bebas dengan terikat sebesar 0,854 yang menunjukkan hubungan sangat kuat dan positif. Pengaruh dan hubungan positif artinya semakin tinggi penggunaan media pembelajaran online, maka akan semakin tinggi pula hasil belajar kognitif mahasiswa dan sebaliknya. Keterkaitan hubungan antara variabel sangat kuat menunjukkan hubungan timbal balik yang sangat kuat antar variabel.

b. Dari tabel model summary diperoleh nilai koefisien determinasi sebesar 0,710, ini menunjukkan bahwa pengaruh media pembelajaran online terhadap variabel hasil belajar kognitif mahasiswa STK St. Yakobus Merauke sebesar 71\%. Hal ini berarti variabel hasil belajar kognitif juga dipengaruhi oleh variabel lain yang tidak diteliti sebesar 29\%. Pengaruh variabel bebas terhadap variabel terikat di sini tergolong besar karena menunjukkan angka lebih dari 50\%.

c. Dari model regresi yang diteliti diperoleh persamaan regresi untuk model penelitian ini yaitu $\mathrm{Y}=4,296+0,024 \mathrm{X}$. Artinya dalam keadaan konstan (0) tanpa adanya pengaruh dari variabel bebas (pembelajaran online), hasil belajar mahasiswa bernilai 4,296. Apabila nilai pembelajaran online dinaikan menjadi 10 basis poin, maka hasil belajar kognitif mahasiswa akan meningkat menjadi 4,536 poin.

\section{Saran}

Berdasarkan kesimpulan di atas, penulis memberikan beberapa saran berikut:

a. Pihak kampus dapat lebih meningkatkan frekuensi dan efektivitas penggunaan media pembelajaran online di masa pandemi covid-19 sebagai media pembelajaran dalam proses perkuliahan mengingat pengaruhnya yang cukup besar dan signifikan terhadap hasil belajar mahasiswa. Untuk itu diperlukan kesiapan sarana, prasarana dan sumber daya manusia (dosen dan mahasiswa) yang memadai agar penerapan pembelajaran online dapat berlangsung efektif dan efisien. Apabila kondisi ini tidak 
tercapai atau terkesan pelaksanaannya cenderung dipaksakan maka yang terjadi adalah sebaliknya, yaitu penurunan kualitas proses pembelajaran yang berdampak sangat signifikan terhadap hasil belajar kognitif mahasiswa (hubungan timbal-balik antar variabel).

b. Pihak kampus lebih meningkatkan keterampilan dosen dalam mengembangkan modul pembelajaran berbasis daring (online) dan keterampilan penggunaan aplikasi pembelajaran online melalui pelatihan dan/atau workshop yang relevan. Selama ini sejauh pengamatan penulis, pelatihan penggunaan aplikasi pembelajaran online belum dilaksanakan secara kontinu dan terintegrasi. Dosen juga perlu dilatih menyusun bahan ajar berbasis daring untuk menunjang proses pembelajaran secara online (e-learning).

c. Pihak kampus dapat membantu meningkatkan literasi digital mahasiswa khususnya yang berasal dari pedalaman. Pembiasaan teknologi digital dapat dilakukan secara sederhana misalnya dengan mencari referensi dari internet, mengirimkan tugas via media sosial atau email, membuat resensi dari artikel digital, membagikan bahan perkuliahan melalui cloud untuk diunduh mahasiswa, memberikan penugasan di laboratorium komputer, memberikan tugas presentasi dengan program PowerPoint, upload video melalui kanal streaming seperti Youtube, dll.

d. Pihak kampus hendaknya memberikan dukungan dan fasilitas jejaring internet yang kuat dan stabil bagi mahasiswa untuk mendukung proses belajar. Selama ini jaringan wifi (hotspot) sudah disediakan di kampus namun beberapa mahasiswa masih terkendala untuk mengakses dikarenakan minimnya kepemilikan gawai dan perangkat digital. Oleh karena itu penulis menyarankan agar laboratorium komputer dapat diakses setiap jam perkuliahan oleh mahasiswa dan disediakan beberapa perangkat komputer di ruang baca perpustakaan untuk mengakses konten-konten digital.

e. Pihak kampus meningkatkan fungsi kontrol akses internet mahasiswa selama di kampus. Hal ini sangat diperlukan agar mahasiswa dapat terkontrol dalam menggunakan akses internet yang ada secara tepat guna demi perkembangan proses belajar mereka di kampus.

f. Perlu diupayakan pemberian subsidi bantuan kuota internet bagi mahasiswa. Sejauh yang penulis amati, belum ada bantuan subsidi kuota internet bagi mahasiswa secara langsung. Pihak kampus perlu mencari sumber pendanaan alternatif di luar kementerian agama untuk merealisasikan program ini mengingat pandemi Covid19 yang belum berakhir dan keperluan penggunaan kuota internet bagi mahasiswa dan dosen untuk proses belajar mengajar sangat tinggi.

\section{Daftar Kepustakaan}

Anas Sudijono. 2011. Pengantar Evaluasi Pendidikan. Jakarta: PT Rajagrafindo Persada.

Arief S. Sadiman, dkk. 1996. Media Pendidikan: Pengertian, Pemanfaatan, dan Pengembangannya. Jakarta: CV. Rajawali.

Aristo Rahadi. 2003. Media Pembelajaran. Jakarta: Depdiknas.

Bretz, Rudy. 1971. The A Taxonomy of Communication Media. New Jersey: Educational Technology Publications.

Daryanto. 2010. Evaluasi Pendidikan. Jakarta: PT Rineka Cipta. 
Elliot, Stephen N. 2000. Educational Psychology: Effective teaching, Effective learning. Boston: McGraw-Hill.

Hartley, Darin E. 2001. Selling E-Learning. Alexandria: ASTD Publications.

Ismiasri, T. 2011. Pemanfaatan Teknologi Multimedia dalam Pembelajaran Matematika. Blitar: STKIP.

Laughey, D. 2007. Themes in Media Theory. New York: Open University Press.

Molinda, Michael. 2005. Instrucsional Technology and Media for Learning. New Jersey: Colombus.

Muhibbin Syah. 2009. Psikologi Pendidikan dengan Pendekatan Baru. Bandung: PT Remaja Rosdakarya.

Ngalim Purwanto. 2010. Prinsip-prinsip dan Teknik Evaluasi Pengajaran. Bandung: PT Remaja Rosdakarya.

Sugiyono. 2012. Metode Penelitian Kuantitatif, Kualitatif dan R\&D. Bandung: Alfabeta.

Winkel, W.S. 1996. Psikologi Pengajaran. Jakarta: Gramedia Widiasarana Indonesia.

Yazdi, M. 2012. E-Learning Sebagai Media Pembelajaran Interaktif Berbasis Teknologi Informasi. Jurnal Ilmiah Foristek, Fakultas Matematika dan Ilmu Pengetahuan Alam Universitas Tadulako. 